\title{
The Examination of Teacher Candidates' Democratic Values in Terms of Various Variables: the Case of Faculty of Educational Sciences*
}

\author{
Uğur Akın** \\ Murat Özdemir***
}

\begin{abstract}
The purpose of this study was to understand the democratic values of teacher candidates in Ankara University. 176 teacher candidates from Faculty of Educational Sciences in Ankara University constituted the study group. Data were collected using 24items Teacher Trainees' Democratic Values Scale (TTDVS) scale which was developed by Selvi. The democratic values of teacher candidates were analyzed under three sub-scales: right to education, freedom and solidarity. Results indicate that teacher candidates' democratic values were quite high. Female teacher candidates had more democratic values as compared to male teacher candidates. Similarly those who join in non-governmental organizations (NGO) had more democratic values than those who do not. On the other hand, department and monthly expense had no differential effect on teacher candidates' democratic values.
\end{abstract}

Key Words: Teacher candidates, democracy, democratic values

\footnotetext{
* We would like to thank to Prof. Dr. Ali Balcı for his contribution from department of Educational Administration and Policy in Faculty of Educational Sciences in Ankara University.

Research Assistant Ankara University, Faculty of Educational Sciences, uakin@education.ankara.edu.tr

${ }^{* * *}$ Doctoral Student, Institution of Educational Sciences, mrtozdem@gmail.com
} 


\section{SUMMARY}

Purpose and Significance: The concept of "democracy" has Greek origin. In the old Greek, the concept of democracy has two different roots. The first part of the term is "demos" which means public and the second part is "crasia" which means sovereignty or power. As a result, the term is used for the sovereignty of public. At first, the term had political content and was used as a type of government. But throughout the history its meaning has changed and used for expression of a kind of attitudes of people. Meanwhile, democracy has become the part of values system. All societies in the world have a sort of value system which is transmitted to new generations through educational practices. Therefore, it can be argued that education plays a vitally important role in construction of democratic societies. In this process schools and classroom practices are determining factors for helping students to internalize the democratic values. Since teachers are crucial role model for their pupils, it might be thought that their attitudes are the most effective way of teaching democratic values. The debate whether democratic values can be taught with education or not deepened the discussion on education of teacher candidates. The assumption that the democratic values can be taught is also true for teacher candidates. For this reason the current study is mainly questioning the relationship between democratic values of teacher candidates and several variables such as gender, income per month, department and membership to NGOs.

Methods: Participants of this study were 176 teacher candidates from Faculty of Educational Sciences in Ankara University. In the research the scale developed by Selvi (2006) was used to determine the level of participants' democratic values. Then, some statistical techniques including frequencies, $t$-test, ANOVA and the test of Kruskal-Wallis $\mathrm{H}$ were used to analyze the data.

Results: Research findings show that teacher candidates' democratic values are quite high. There is a significant difference between gender and democratic values of students. There is also a significant difference between membership to any non-governmental organization and democratic values. But results do not indicate any relationship between incomes per month and democratic values of students. And lastly there is not significant relationship between students' departments and their democratic values.

Conclusions: The findings of current research imply that female teacher candidates have more democratic values as compared to males. It can also be concluded that being a member of any non-governmental organization may result in more democratic values or vice versa. With the result of this study it can be thought that students' departments and their expenditures per month show little or any effect on their democratic values. 


\title{
Öğretmen Adaylarının Demokratik Değerlerinin Çeşitli Değişkenler Açısından İncelenmesi: Eğitim Bilimleri Fakültesi Örneği"
}

\author{
Ŭ̆ur Akın** \\ Murat Özdemir***
}

\begin{abstract}
ÖZ. Bu çalışmanın amacı Ankara Üniversitesi Eğitim Bilimleri Fakültesi'nde öğrenim görmekte olan öğretmen adaylarının demokratik değerlerini çeşitli değişkenler açısından incelemektir. Çalışma grubunu Ankara Üniversitesi Eğitim Bilimleri Fakültesi'nde öğrenim görmekte olan 400 öğrenci arasından rastgele seçilen 176 dördüncü sınıf öğrencisi oluşturmaktadır. Çalışmada öğretmen adaylarının demokratik değerleri, Selvi (2006) tarafından geliştirilmiş olan "Öğretmen Adayları Demokratik Değerler Ölçeği" ile ölçülmüştür. Öğretmen adaylarının demokratik değerleri,"eğitim hakkı", "dayanışma" ve "özgürlük" alt boyutlarında incelenmiştir. Elde edilen bulgular, öğretmen adaylarının demokratik değerlerinin yüksek olduğunu göstermiştir. Ayrıca kadın öğretmen adaylarının ve herhangi bir sivil toplum kuruluşuna üye olan adayların daha yüksek demokratik değerlere sahip oldukları görülmüştür. Bunun yanında öğretmen adaylarının demokratik değerlerinin okumakta oldukları bölümlere ve aylık ortalama harcama miktarlarına göre anlamlı bir şekilde farklılaşmadığı görülmüsşür.
\end{abstract}

Anahtar Sözcükler: Öğretmen adayları, demokrasi, demokratik değerler

\footnotetext{
* Katkılarından dolayı Ankara Üniversitesi Eğitim Bilimleri Fakültesi Eğitim Yönetimi ve Politikası öğretim üyelerinden Prof. Dr. Ali Balcı'ya teșekkür ederiz.

${ }^{* *}$ Araştırma Görevlisi Ankara Üniversitesi, Eğitim Bilimleri Fakültesi, uakin@education.ankara.edu.tr

${ }^{* * *}$ Eğitim Bilimleri Enstitüsü Doktora Öğrencisi, mrtozdem@gmail.com
} 


\section{GİRIŞ}

Demokrasi sözcüğünün etimolojik kökeni eski Yunanca'dan gelmektedir. Eski Yunanca'da "demos" sözcüğü halk anlamında kullanılırken "krasia" sözcüğü iktidar ya da egemenlik anlamında kullanılmıştır. Dolayısıyla demokrasi sözcüğü "halkın egemenliği" anlamına gelmektedir (Şaylan, 1998, 13). Görüldüğü gibi geleneksel anlamda demokrasi sözcügünün ilk kullanımı siyasal bir içeriğe sahiptir. Ancak demokrasi sözcügü süreç içerisinde siyasal anlamının dişına taşmış ve anlam içeriği giderek zenginleşen bir kavrama dönüşmüştür. Bu haliyle demokrasi, bir tutum ya da davranış biçimini anlatmakta kullanılan bir kavram haline gelmiştir.

Diğer yandan demokrasi, değerler sisteminin önemli bir bileşenidir. Dünyadaki tüm toplumlar bir değerler sistemine sahiptir. Bu değerler sistemi, eğitim aracılığıyla yetişmekte olan kuşaklara aktarılmaktadır. Değerler sisteminin en önemli göstergesi bireylerin tutum ve davranışlarıdır. Eğitimin en önemli rolü ise bireylerin kişilikleri üzerinde etkide bulunarak onların tutum ve davranışlarını değiştirmektir. Formal ya da informal olsun, eğitimin öncelikli amaçlarından birinin, bireylerin olay ve olgular hakkındaki farkındalıklarını geliştirmek olduğu dile getirilebilir. Diğer bir deyişle eğitim aracılığı ile bireylerin inanç sistemleri üzerinde etkide bulunulduğu ve kimi olay ve olgular hakkındaki tutumları değiştirilmeye çalışıldığ 1 ileri sürülebilir. Bu bakışla, eğitim süreciyle birlikte bireylerin olay ve olgulara doğru ya da yanlış penceresinden bakmaya başladığı ve davranışlarının da sözü edilen eğitim süreciyle birlikte biçimlendiği söylenebilir (Sharma, 2003, 212).

Bireylerin değer sistemini içselleştirmeleri ilk olarak ailede başlamakta ve okulda devam etmektedir. Okulun, bireylerin sahip oldukları değerleri biçimlendirmesi konusunda kimi farklı görüşler bulunmaktadır. Bazılarına göre çocuklar olabildiğince özgür bırakılmalı ve kendi değer sistemlerini kendileri geliştirmelidir. Oysa bunun tam karşıtı görüşe göre, okul, etkin bir biçimde çocukların değer sistemi üzerinde etkide bulunmak için çaba göstermelidir (Sharma, 2003, 212). Bu değerlerden biri olan demokratik yurttaşlık bilincinin geliştirilmesinde okulun yadsınamaz bir payı olduğundan söz edilmektedir (Schweisfurth, 2002). Bu konudaki öncü niteliğindeki çalışmalarında Dewey (1965) eğitimin demokratik toplumun en önemli unsurlarından biri olduğundan söz etmektedir.

Bir değer olarak demokrasinin bireylere kazandırılmaya çalışılmasının ardındaki temel gerekçe, demokratik bir siyasal sistem ve toplumsal yapının gelişimine katkı sağlamaktır. Çünkü demokratik değerler eğitimi ve siyasal bir sistem olarak demokrasi arasında çok yönlü bir ilişkiler ağı olduğu genel kabul gören bir anlayıştır (Middaugh ve Perlstein, 2005). 
Yukarıda söz edilen tartışmalar, okullarda ne tür demokratik değerlerin öğrencilere kazandırılması gerektiği yönündeki tartışmaları da beraberinde getirmiştir. Örneğin, Moller'e (2006) göre demokratik değerleri benimsemiş bireyler, temel hak ve özgürlüklerin bilincinde olmalı, diğer insanların görüşlerini hesaba katabilmeli, bilinçli kararlar alabilmeli (ideolojilere veya geleneklere körü körüne bağlılık duymamalı), çoğulcu olmalı ve farklılıkları kabullenebilmeli, eşitlik ve adaleti savunmalıdır. Puolimatka'ya göre (1997) ise bir değer olarak demokrasi eğitimi, demokrasinin gelişmesi ve pekiştirilmesi açısından büyük önem taşımaktadır. Demokrasinin gelişmesi için insanların "birey" olmayı ve başkalarının haklarına değer vermeyi öğrenmeleri gerekmektedir. Tezcan'a $(1996,103)$ göre ise demokrasi ve eğitim arasında çok sıkı bir bağ bulunmaktadır. Buna göre demokratik toplumlardaki bireylerin akıllı, esnek ve değişime hazır olması gerekmektedir. Okul, öğrencilerine, olay ve olgulara farklı pencerelerden bakabilme alışkanlığı kazandırabilmeli ve onların açık fikirli olmaları yönünde çaba göstermelidir. Açık fikirli olmak, başkalarının düşüncelerine sayg1 duymayı ve onların görüşlerini anlamayı ve kavramayı ifade etmektedir. Karakütük $(2001,20)$ de okulun aile ve devletle birlikte demokratik yaşamın ayrılmaz bir parçası olduğunu belirtmektedir. Yazara göre okulun demokratik değerlerle yönetilmesi ve demokratik bir eğitimin sunulması öğrencilerin demokrasiyi benimsemesi ve demokratik değerleri içselleştirmesi için gereklidir.

Okullarda öğrencilere demokratik değerlerin benimsetilmesi büyük oranda okulun kendisinin demokratik yapıda olup olmadığ ${ }_{1}$ ile ilgilidir. $\mathrm{Bu}$ yöndeki tartışmaların kökenini 17. ve 18. yüzyıllara kadar götürmek mümkündür. Bu yüzyıllarla birlikte başlayan hızlı sanayileşme süreci kırsal düşünme alışkanlıklarını da değiştirmeye başlamıştır. Özellikle sözü edilen hızlı değişim sürecinin en önemli yansımalarından birini de daha demokratik okul yapısının kurumsallaşması oluşturmuştur (Fine, 1945, 34).

Okulun demokratik olup olmadığının en önemli göstergesi okullardaki karar alma sürecidir. Son yıllarda okullarda, öğrenci, öğretmen ve velilerin okul yönetimi ile işbirliği içerisine girmeleri ve karar alma süreçlerine etkin katılımlarının sağlanmasına yönelik beklentiler giderek artmaktadır. Nitekim alanyazında bu yönde yapılmış kimi çalışmalara rastlamak mümkündür. Özellikle okul politikaları ve öğretim programlarının belirlenmesi sürecine okul paydaşlarının katılımının, demokratik bir okul iklimi yaratılmasına katk1 sağlayabileceği öne sürülmektedir. Bu düşüncenin ardındaki temel varsayım, öğretmenlerin okullarda alınan kararlara etkin katılımının, sonuçta daha iyi bir öğrenme ve öğretme ortamının yaratılmasına katkı sağlayacağıdır (Myers, 2008). Nitekim yönetim ve örgüt alanyazını 
incelendiğinde "itaat" kavramının giderek terk edilmeye başlandığı bunun yerine "katılım" kavramının öne çıktığını görmek mümkündür (Özden, 2005, 94). Örgüt içi demokrasinin gelişimi ast-üst ilişkilerinin ve insan ilişkilerinin iyileşmesini, yönetsel kararların sağlıklı olmasını ve bunların tam uygulanmasını sağlayacağı da öne sürülmektedir (Başaran, 2006, 227).

Okullarda demokratik değerlerin bulunması gereken alanların başında sınıflar gelmektedir. Bir araştırma sonucuna göre, öğrenciler sınıflarında konuları en iyi şekilde açılayabilen, kendileriyle bireysel olarak ilgilenebilen, ödül ve ceza kullanımında adaletli davranabilen, yeteri kadar sert ama otoriter olmayan, şakacı ama iğneleyici olmayan öğretmenler istemektedir (Wragg ve Wragg, 1998). Sınıf içi demokrasi konusu alanda büyük ilgi görmüş ve bu konuda pek çok araştırma yapılmıştır. Yapılan araştırmalar ağırlıklı olarak öğretmenin öğrencilerine yönelik tutumları ve sınıf kurallarının belirlenmesi sürecine öğrenci katılımının düzeylerinin belirlenmesi üzerinde yoğunlaşmaktadır. Başar’a $(2006,79)$ göre demokratik bir lider olarak öğretmen, öğrenci görüsslerini almalı, yapılacak işler konusunda onlarla uzlaşmalı ve çalışma düzenlerini seçmeleri konusunda öğrencilerine seçme hakkı tanımalıdır. Öte yandan Arslan $(2007,62)$ sınıf kurallarının geliştirilmesi ve öğrencilere öğretilmesi sürecinin önemine dikkat çekmekte bu kararların alınması sürecinde öğrencinin etkin katılımının sağlanması gerektiğini belirtmektedir. Sınıf kurallarının öğrenciler ile birlikte alınmamasının bir sonucu olarak gerek kuralların uygulanmasında ve gerekse öğrencilere demokratik değerlerin kazandırılmasında kimi sorunların ortaya çıkması kaçınılmaz olacaktır.

Tıpk1 diğer yönetim alanlarında olduğu gibi sınıf yönetiminde de geçmişten günümüze otoriter bir yönetim anlayışından demokratik bir yönetim anlayışına geçişin olduğu söylenebilir. Öğretmen-öğrenci iliş̧kilerinde çağdaş yaklaşım, demokratik yönetim anlayışını içermektedir. Demokratik yönetimin sergilendiği eğitim ortamlarında daha az disiplin sorunu çıkmakta, öğrenciler daha iyi birer yurttaş haline gelmekte ve daha başarılı olmaktadır (Black, 2005). Sinıflarda demokratik bir yönetimin sergilenmesi ise öğretmenlerin demokratik değerlere sahip olması ile mümkündür. $\mathrm{Bu}$ durumda öğretmenlerin demokratik değerlere sahip olmalarının hem öğrencilere demokratik değerlerin benimsetilmesi hem de sınıf içi etkinliklerin başarılı bir şekilde yürütülmesi açısından önemli olduğunu ileri sürmek yanlış olmayacaktır.

Öte yandan sinıf, kendine özgü özellikleriyle bir toplum meydana getirmektedir. Ortak amaçlarla bir araya gelen bu topluluğun düzen içinde yaşaması gerekmektedir. Aksi takdirde yoğun çaba ve dikkat gerektiren sınıf etkinlikleri aksayacaktır (Aksoy, 2002, 13-14). Diğer bir deyişle, sınıftaki demokratik ortam sınırsız özgürlük anlamına da gelmemektedir. 
Görüldüğü gibi sınıfta demokratik bir ortam oluşturmak, eğitimin beklenen sonuçları doğurması bakımından önemlidir. Demokratik bir sınıf ortamında yetişen öğrenciler hem akademik olarak daha başarılı olmakta hem de demokratik yaşam tarzını içselleștirmektedir. O halde öğretmenlerin demokratik bir sınıf ortamı oluşturma konusunda bilinçli ve istekli olması önemli görülebilir. Demokratik bir okul ve sınıf ortamının oluşmasına en büyük katkının ise demokratik değerleri içselleştirmiş öğretmenler tarafından sağlanacağı düşünülmektedir (Karadağ ve diğerleri, 2006).

Öğretmenlerin demokratik değerlerinin çeşitli açılardan ele alınıp incelendiği çalışmalar hem görev başındaki öğretmenlere (Okçabol, ve Gök, 1998; Rowland, 2003; Black, 2005; Karadağ, Baloğlu ve Yalçınkayalar 2006) hem de aday öğretmenlere (Ĕgitim Fakültesi öğrencileri) (Demoulin ve Kolstad, 2000; Karahan, Sardoğan, Özkamal1, Dicle, 2006; Selvi, 2006; Gömleksiz ve Kan, 2008) yönelik olarak yapılmıştır. Ancak özellikle eğitim fakültelerindeki öğretmen adaylarının demokratik değerlerinin araştırılması ve adayların öğretmenliğe başlamadan önceki demokratik değerleriyle ilgili yapılabileceklerin gözden geçirilmesi önemli görülmektedir.

Bu düşünceden yola çıkarak, bu çalışmanın amacı Ankara Üniversitesi Eğitim Bilimleri Fakültesi’nde eğitim görmekte olan öğretmen adaylarının sınıf ortamındaki demokratik değerlerinin genel görünümüne göz atmak ve bu değerlerdeki farklılaşmayı çeşitli değişkenler açısından incelemektir. Bu amaç çerçevesinde şu sorulara yanıt aranmıştır:

1. Ankara Üniversitesi Eğitim Bilimleri Fakültesi'nde eğitim görmekte olan öğretmen adaylarının demokratik değerleri ne düzeydedir?

2. Öğretmen adaylarının demokratik değerleri eğitim hakkı, dayanışma ve özgürlük alt boyutlarında;

a) Cinsiyete göre,

b) Sivil toplum kuruluşu üyeliğine göre,

c) Okumakta oldukları bölüme göre ve

d) Aylık ortalama harcama miktarlarına göre anlamlı şekilde farklılaşmakta mıdır?

\section{YÖNTEM}

Eğitim araştırmalarının çoğu tarama türünde yapılmaktadır (Chromy, 2006, 641). Tarama araştırmalarının amacı bireylerin, grupların ya da örgütlerin ilgilenilen özelliklerini betimlemektir (Berends, 2006, 623). Öğretmen adaylarının demokratik değerlerini betimlemeyi amaçlayan bu araştırma da betimsel tarama türünde desenlenmiştir. Araştırmada kullanılan ölçme aracı ve verilerin analizine ilişkin bilgiler aşağıda açıklanmaktadır. 


\section{Çalışma Grubu}

Çalışmanın grubu 2007-2008 öğretim yılında Ankara Üniversitesi Eğitim Bilimleri Fakültesi’nde okumakta olan 400 dördüncü sınıf öğrencisi arasından (öğretmen adayları) rastgele seçilmiştir. Çalışma kapsamında 250 öğretmen adayına ulaşılmaya çalışılmıştır. Altı farklı öğretmenlik programında okumakta olan öğretmen adaylarına uygulanan 250 anketten 176's1 analizler için uygun (kayıp verilerin çokluğu ve anketin doldurulması açısından) bulunmuştur. Bölüm içindeki öğretmen adayları ise yansız atama ile belirlenmiştir. Çalışma grubuna alınan öğretmen adaylarının bağımsız değişkenlere göre sayıları Çizelge 1'de verilmiştir.

Çizelge 1. Öğretmen Adaylarının Bağımsız Değişkenlere Göre Sayıları

\begin{tabular}{|c|c|c|c|}
\hline & Değișken & & $\mathbf{N}$ \\
\hline \multirow{17}{*}{ ق. } & \multirow{7}{*}{ 害 } & Bilgisayar ve Öğretim Teknolojileri Eğitimi & 28 \\
\hline & & Okul Öncesi Öğretmenliği & 30 \\
\hline & & Rehberlik ve Psikolojik Danışmanlık & 51 \\
\hline & & Sınıf Öğretmenliği & 20 \\
\hline & & Sosyal Bilgiler Öğretmenliği & 19 \\
\hline & & Zihin Engelliler Öğretmenliği & 28 \\
\hline & & Toplam & 176 \\
\hline & \multirow{3}{*}{ 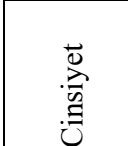 } & Kadın & 129 \\
\hline & & Erkek & 47 \\
\hline & & Toplam & 176 \\
\hline & \multirow{3}{*}{ 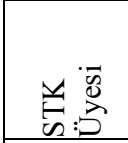 } & Üye & 30 \\
\hline & & Üye Değil & 146 \\
\hline & & Toplam & 176 \\
\hline & \multirow{4}{*}{ 蒫 } & 300 TL'den az & 69 \\
\hline & & $300-500 \mathrm{TL}$ & 70 \\
\hline & & 500 TL'den çok & 37 \\
\hline & & Toplam & 176 \\
\hline
\end{tabular}

Çizelge 1'de görüldüğü gibi veri toplama süreci sonunda dönen anket sayısı 176 (dönüş oranı=\%70,4) olmuş ve çalışma bu verilerle yürütülmüştür.

\section{Ölçme Aracı}

Öğretmen adaylarının eğitim yaşantısına ilişkin demokratik değerleri Selvi (2006) tarafindan geliştirilen "Öğretmen Adayları Demokratik Değerler Ölçeği” ile belirlenmiştir. Ölçek "Eğitim Hakkı" (9 madde), 
"Dayanışma" (9 madde) ve "Özgürlük" (6 madde) olmak üzere üç alt boyut ve 24 maddeden oluşmakta olup ölçeğin 1 . ve 7 . maddeleri tersten puanlanmaktadır. Geliştirme çalışmasında ölçeğin Crobnach Alpha güvenirlik katsayıs1 .87 olarak hesaplanmıştır. Cronbach Alpha değeri bu çalışma için de hesaplanmış ve yine. 87 olarak bulunmuştur. Bu bulgudan hareketle ölçeğin bu çalışma için de güvenilir olduğu kanısına varılmıştır.

\section{Verilerin Analizi}

Toplanan veriler SPSS 13.00 programı kullanılarak analiz edilmiştir. Verilerin analizinde; frekans, t-testi, ANOVA ve Kruskal-Wallis $H$ testleri kullanılmıştır.

\section{BULGULAR ve YORUM}

Çalışmanın amacına uygun olarak bu başlık altında öncelikle öğretmen adaylarının demokratik değerler ölçeğinden aldıkları puanların genel görünümüne bakılmıştır. Daha sonra öğretmenlerin ölçeğin "eğitim hakkı", "dayanışma" ve "özgürlük" alt boyut puanlarında cinsiyet, sivil toplum kuruluşu üyeliği, okunulan bölüm ve aylık ortalama harcama miktarı bağımsız değişkenlerine bağlı olarak anlamlı farklılaşma olup olmadığı incelenmiştir.

\section{Öğretmenlerin Demokratik Değerlerinin Genel Görünümü}

Öğretmen Adayları Demokratik Değerler Ölçeği'nden en az 24, en çok 120 puan alınabilmektedir (olumsuz maddeler düzeltildiğinde). Yüksek puanlar yüksek, düşük puanlar ise düşük demokratik değerlere işaret etmektedir (Selvi, 2006). Bu çalışmaya katılan öğretmen adaylarının ölçekten aldıkları puanlar 66 ile 115 arasında değişmiş̧tir (ort=103,17; ss=7,41). Katılımciların \% 30,1'i 66-100 arasinda puan alırken \%69,9'u 101115 arasında puanlar almıştır. $\mathrm{Bu}$ durum çalışma grubundaki öğretmen adaylarının genellikle yüksek demokratik değerlere sahip oldukları şeklinde yorumlanabilir.

\section{Cinsiyet Değişkenine Göre Farklılaşma}

Öğretmen adaylarının demokratik değerlerinde cinsiyete göre anlamlı bir farklılaşma olup olmadığını belirlemek üzere t-testi yapılmıştır. Analiz sonuçları Çizelge 2'de yer almaktadır. 
Çizelge 2. Öğretmen Adaylarının Demokratik Tutumlarında Cinsiyete Göre Farklılaşma

\begin{tabular}{|c|c|c|c|c|c|c|c|c|}
\hline Ölçek & & Cinsiyet & $\mathrm{N}$ & $\bar{X}$ & $\mathrm{~S}$ & $\mathrm{sd}$ & $\mathrm{t}$ & $\mathrm{p}$ \\
\hline \multirow{6}{*}{$\begin{array}{l}\text { Demokratik } \\
\text { Değer }\end{array}$} & Eğitim & Kadin & 129 & 42,35 & 3,34 & \multirow{2}{*}{174} & \multirow{2}{*}{, 518} & \multirow{2}{*}{, 605} \\
\hline & Hakk1 & Erkek & 47 & 42,06 & 3,23 & & & \\
\hline & \multirow{2}{*}{ Dayanışma } & Kadın & 129 & 40,85 & 3,61 & \multirow{2}{*}{174} & \multirow{2}{*}{1,939} & \multirow{2}{*}{, $054^{*}$} \\
\hline & & Erkek & 47 & 39,63 & 3,84 & & & \\
\hline & \multirow{2}{*}{ Özgürlük } & Kadın & 129 & 20,63 & 2,04 & \multirow{2}{*}{174} & \multirow{2}{*}{2,811} & \multirow{2}{*}{, $006^{*}$} \\
\hline & & Erkek & 47 & 19,63 & 2,19 & & & \\
\hline
\end{tabular}

$* \mathrm{p} \leq .05$

Çizelge 2'de görüldüğü gibi öğretmen adaylarının demokratik değerleri eğitim hakkı boyutunda cinsiyete göre anlamlı şekilde farlılaşmazken (p> $.05)$, dayanışma boyutunda $\left(\mathrm{t}_{(174)}=1,939 ; \mathrm{p}<.05\right)$ ve özgürlük boyutunda $\left(\mathrm{t}_{(174)}=2,811 ; \mathrm{p}<.05\right)$ erkekler ve kadinların puanları arasında anlamlı farklılaşma bulunmaktadır. Ortalamalar dikkate alındığında dayanışma boyutunda kadınların $(\bar{X}=40,85)$ erkeklerden $(\bar{X}=39,63)$ anlamlı şekilde daha fazla demokratik değere sahip olduğu görülmektedir. Yine özgürlük boyutunda da kadınlar $(\bar{X}=20,85)$ erkeklerden $(\bar{X}=19,63)$ daha fazla demokratik değere sahiptir. Özgürlük boyutundaki farklılaşma, özellikle genç ve eğitimli kadınlar arasında yerini bulan özgürlük, kadın-erkek eşitliği gibi söylemlerin etkisine bağlanabilir.

Alanyazında öğretmen adaylarının demokratik değerleri ve cinsiyet değişkeni arasındaki ilişkiyi sorgulayan kimi araştırmalar bulunmakta ve söz edilen bu çalışmalara göre kadın öğrenciler ile erkek öğrencilerin demokratik tutumları anlamlı bir biçimde farklılaşmaktadır. Buna göre kadın öğrenciler erkek öğrencilere göre daha fazla demokratik tutuma sahiptir (Gömleksiz ve Kan, 2008; Karahan ve diğerleri, 2006). Demoulin ve Kolstad'ın (2000) 1452 öğretmen adayı üzerinde gerçekleştirdikleri araştırmada da kadın öğretmen adaylarının erkek öğretmen adaylarına göre daha fazla demokratik olgunluğa sahip oldukları sonucuna ulaşılmıştır. Bunun yanında Karahan ve diğerleri (2006) öğretmen adaylarının demokratik tutumlarını ele aldıkları araştırmada cinsiyet değişkenine bağlı anlamlı bir farklılık saptanamamıştır. Ancak Karahan ve diğerleri'nin araştırmasında da kadın öğretmen adaylarının demokratik tutum puanlarının erkek öğretmen adaylarının demokratik tutum puanlarından yüksek olduğunu vurgulamakta yarar vardır.

Karaman-Kepenekçi’nin (2006) araştırmasında da kadın öğrencilerin çocuk haklarına karşı daha olumlu tutuma sahip oldukları sonucuna ulaşılmıştır. $\mathrm{Bu}$ bulgunun da demokratik değerle ilgili olabileceği düşünülmektedir. Böylece bu boyutta araştırma bulgularının mevcut alanyazınla uyuştuğu söylenebilir. 


\section{Sivil Toplum Kuruluşu Üyeliği Değişkenine Göre Farklılaşma}

Öğretmen adaylarının demokratik değerlerinde herhangi bir derneğe ya da sivil toplum kuruluşuna üye olup olmama durumlarına göre anlamlı bir farklılaşma olup olmadığını belirlemek üzere t-testi yapılmıştır. Analiz sonuçları Çizelge 3 'te yer almaktadır.

Çizelge 3. Sivil Toplum Kuruluşu Üyeliği Durumlarına Göre Farklılaşma

\begin{tabular}{|c|c|c|c|c|c|c|c|c|}
\hline Ölçek & & Üyelik & $\mathrm{N}$ & $\bar{X}$ & S & sd & $\mathrm{t}$ & $\mathrm{p}$ \\
\hline \multirow{6}{*}{$\begin{array}{l}\text { Demokratik } \\
\text { Değer }\end{array}$} & Eğitim & Evet & 30 & 43,83 & 2 & \multirow{2}{*}{174} & \multirow{2}{*}{2,885} & \multirow{2}{*}{, $004 *$} \\
\hline & Hakk1 & Hayır & 146 & 41,95 & 3,43 & & & \\
\hline & \multirow{2}{*}{ Dayanışma } & Evet & 30 & 42,23 & 2,64 & \multirow{2}{*}{174} & \multirow{2}{*}{2,822} & \multirow{2}{*}{, $005 *$} \\
\hline & & Hayır & 146 & 40,17 & 3,79 & & & \\
\hline & \multirow{2}{*}{ Özgürlük } & Evet & 30 & 21,56 & 1,95 & \multirow{2}{*}{174} & \multirow{2}{*}{3,498} & \multirow{2}{*}{, $001 *$} \\
\hline & & Hayır & 146 & 20,12 & 2,07 & & & \\
\hline
\end{tabular}

*p $\leq .05$

Çizelge 3'te görüldüğü gibi öğretmen adaylarının demokratik değerleri eğitim hakkı boyutunda $\left(\mathrm{t}_{(174)}=1,939 ; \mathrm{p}<.05\right)$, dayanışma boyutunda $\left(\mathrm{t}_{(174)}=\right.$ $1,939 ; \mathrm{p}<.05)$ ve özgürlük boyutunda $\left(\mathrm{t}_{(174)}=2,811 ; \mathrm{p}<.05\right)$ herhangi bir derneğe ya da sivil toplum kuruluşuna üye olup olmama durumlarına göre anlamlı şekilde farklılaşmaktadır. Ortalamalar dikkate alındığında eğitim hakkı boyutunda (üye $X=43,83$; değil $X=41,95$ ), dayanışma boyutunda (üye $\bar{X}=$ 42,23 ; değil $X=40,17$ ) ve özgürlük boyutunda (üye $X=21,56$; değil $X=20,12$ ) herhangi sivil toplum kuruluşuna üye olanların olmayanlara göre anlamlı şekilde daha fazla demokratik değere sahip olduğu görülmüștür. Bu bulgu, Karahan ve diğerleri (2006) tarafindan yürütülmüş olan çalışmanın sonuçları ile uyumludur. Söz konusu araştırmada, öğretmen adaylarına bir sivil toplum örgütünün siyasalkültürel etkinliklerine katılıp katılmadıkları sorulmuş ve bu durumun demokratik tutumlarında anlamlı bir farklılaşma oluşturup oluşturmadığ 1 test edilmiştir. Araştırma sonuçları bir sivil toplum örgütünün siyasal-kültürel etkinliklerine katılan öğretmen adaylarının demokratik tutumlarının katılmayanlara göre anlamlı şekilde daha yüksek olduğunu göstermiştir.

Sivil toplum kuruluşları, belli bir hedefi gerçekleştirmek üzere üyelerinin desteği ve çabalarıyla varlık göstermekte ve halkın katılımını esas almaktadır. Diğer yandan sivil toplum örgütleri demokrasi kültürünün yayılması ve demokrasinin daha işlevsel bir hale gelmesinde de önemli bir rol oynamaktadır (Erdoğan, 1998, 226). Bu durum değerlendirildiğinde, söz konusu kuruluşlara üye olanların demokratik değer düzeylerinin daha yüksek olması beklenen bir sonuçtur. Nitekim Abay (2004), sivil toplum anlayışının demokrasi ile örtüştüğünü ve demokrasi ile sivil toplum örgütleri arasında yadsınamaz bir ilişki bulunduğunu söylemektedir. Bu durum katılımcılık ile açıklanmakta ve katılımcılığın da örgütlenme ile olabileceğine dikkat çekilmektedir. 


\section{Bölüm Değişkenine Göre Farklılaşma}

Öğretmen adaylarının demokratik değerlerinde, okudukları bölüme göre anlamlı bir farklılaşma olup olmadığını belirlemek üzere parametrik olmayan istatistik analizlerden Kruskal-Wallis $\mathrm{H}$ testi yapılmıștır. Bu test normallik varsayımının karşılanamaması nedeniyle ANOVA testinin parametrik olmayan alternatifi (Büyüköztürk, 2005, 158) olarak kullanılmıştır. Analiz sonuçları Çizelge 4'te verilmiştir.

Çizelge 4. Bölüme Göre Farklılaşma

\begin{tabular}{|c|c|c|c|c|c|c|c|}
\hline \multicolumn{2}{|l|}{ Ölçek } & Bölüm & $\mathrm{N}$ & $\begin{array}{l}\text { Sira } \\
\text { Ortalamas1 }\end{array}$ & $\mathrm{Sd}$ & $\chi^{2}$ & $\mathrm{p}$ \\
\hline \multirow{3}{*}{$\begin{array}{l}\text { Demokratik } \\
\text { Değer }\end{array}$} & $\begin{array}{l}\text { Eğitim } \\
\text { Hakk1 }\end{array}$ & $\begin{array}{l}\text { BÖTE } \\
\text { Okul Önc. } \\
\text { Rehberlik } \\
\text { Sinıf Öğr. } \\
\text { Sosyal Bil. } \\
\text { Zihin Eng. }\end{array}$ & $\begin{array}{l}28 \\
30 \\
51 \\
20 \\
19 \\
28 \\
\end{array}$ & $\begin{array}{l}89,41 \\
83,65 \\
91,66 \\
87,40 \\
78,95 \\
94,30 \\
\end{array}$ & 5 & 1,606 & ,900 \\
\hline & Dayanışma & $\begin{array}{l}\text { BÖTE } \\
\text { Okul Önc. } \\
\text { Rehberlik } \\
\text { Sinıf Öğr. } \\
\text { Sosyal Bil. } \\
\text { Zihin Eng. }\end{array}$ & $\begin{array}{l}28 \\
30 \\
51 \\
20 \\
19 \\
28\end{array}$ & $\begin{array}{l}83,34 \\
79,87 \\
90,14 \\
93,10 \\
96,16 \\
91,45 \\
\end{array}$ & 5 & 1,910 & ,861 \\
\hline & Özgürlük & $\begin{array}{l}\text { BÖTE } \\
\text { Okul Önc. } \\
\text { Rehberlik } \\
\text { Sinıf Öğr. } \\
\text { Sosyal Bil. } \\
\text { Zihin Eng. }\end{array}$ & $\begin{array}{l}28 \\
30 \\
51 \\
20 \\
19 \\
28 \\
\end{array}$ & $\begin{array}{l}75,16 \\
98,18 \\
83,05 \\
101,28 \\
83,47 \\
95,68\end{array}$ & 5 & 5,713 &, 335 \\
\hline
\end{tabular}

Çizelge 4'te görüldüğü gibi öğretmen adaylarının demokratik değerlerinde eğitim hakk1, dayanışma ve özgürlük alt boyutlarında anlamlı farklılaşma bulunmamaktadır (tüm alt boyutlar için $\mathrm{p}>.05$ ).

Oysa Gömleksiz ve Kan (2008), öğretmen adaylarının demokratik tutumlarında, okudukları bölümlere göre anlamlı farklılaşmalar olduğu sonucuna ulaşmışlardır. Söz edilen araştırmada Sosyal Bilgiler Öğretmeni adaylarının demokratik tutumları, Fen Bilgisi Öğretmeni adaylarına göre daha yüksek çıkmıştır. İki araştırma arasındaki bu farklılaşmanın kaynağı, bu çalışmada Fen Bilgisi Öğretmenliği Programı öğrencilerinin bulunmayışı olarak düşünülmektedir.

\section{Aylık Ortalama Harcama Değişkenine Göre Farklılaşma}

Öğretmen adaylarının demokratik değerlerinde aylık ortalama harcama miktarlarına göre anlamlı bir farklılaşma olup olmadığını belirlemek üzere tek yönlü varyans analizi (ANOVA) yapılmıştır. Analiz sonuçları Çizelge 5'te verilmiştir. 
Çizelge 5. Aylık Ortalama Harcama Miktarına Göre Farklılaşma

\begin{tabular}{|c|c|c|c|c|c|c|c|}
\hline & & $\begin{array}{l}\text { Harcama } \\
\text { Miktar1 }\end{array}$ & $\mathrm{N}$ & $\mathrm{Sd}$ & $\mathrm{F}$ & $\mathrm{p}$ & $\begin{array}{l}\text { Anlaml1 } \\
\text { Fark }\end{array}$ \\
\hline \multirow{7}{*}{$\begin{array}{l}\text { Demokratik } \\
\text { Değer }\end{array}$} & \multirow[b]{2}{*}{ Eğitim Hakk1 } & $<300 \mathrm{TL}$ & 69 & \multirow{3}{*}{$2-173$} & \multirow{3}{*}{,662 } & \multirow[b]{2}{*}{,517 } & \multirow[b]{2}{*}{ - } \\
\hline & & $300-500 \mathrm{TL}$ & 70 & & & & \\
\hline & \multirow{3}{*}{ Dayanışma } & $\begin{array}{l}>500 \mathrm{TL} \\
<300 \mathrm{TL}\end{array}$ & $\frac{37}{69}$ & & & & \\
\hline & & $300-500 \mathrm{TL}$ & 70 & \multirow[t]{2}{*}{$2-173$} & \multirow[t]{2}{*}{,652 } & \multirow[t]{2}{*}{,522 } & \multirow[t]{2}{*}{ - } \\
\hline & & $>500 \mathrm{TL}$ & 37 & & & & \\
\hline & \multirow[b]{2}{*}{ Özgürlük } & $<300 \mathrm{TL}$ & 69 & \multirow[b]{2}{*}{$2-173$} & \multirow[b]{2}{*}{,572 } & \multirow[b]{2}{*}{,566 } & \multirow[b]{2}{*}{ - } \\
\hline & & $\begin{array}{l}300-500 \mathrm{TL} \\
>500 \mathrm{TL}\end{array}$ & $\begin{array}{l}70 \\
37\end{array}$ & & & & \\
\hline
\end{tabular}

Çizelge 5'teki ANOVA sonuçları incelendiğinde öğretmen adaylarının demokratik değerlerinde eğitim hakkı, dayanışma ve özgürlük alt boyutlarında anlamlı farklılaşma bulunmadığı görülmektedir (tüm alt boyutlar için $\mathrm{p}>.05)$.

$\mathrm{Bu}$ durum; demokratik değerlerin, kişilerin içselleştirmesine bağlı olarak yaşam biçimi haline gelebileceğine ve bireylerin harcama durumlarına göre farklılık göstermeyebileceğine işaret etmektedir. Benzer şekilde Gömleksiz ve Kan (2008) da öğretmen adaylarının demokratik tutumları ile ilgili ailenin gelir durumları arasında bir ilişki olmadığını sonucuna ulaşmışlardır. Böylece bu boyutta araştırma sonuçlarının belirtilen araştırma ile uyumlu olduğunu söylemek olanaklıdır.

\section{SONUÇ VE ÖNERILER}

$\mathrm{Bu}$ araştırma ile Ankara Üniversitesi Eğitim Bilimleri Fakültesi'nde öğrenim görmekte olan öğretmen adaylarının demokratik değerleri, cinsiyet, sivil toplum kuruluşuna üyelik, öğrenim görülmekte olan bölüm ve aylık ortalama harcama değişkenleri dikkate alınarak incelenmiştir. Söz edilen bu değişkenler, araştırmada kullanılan "Öğretmen Adayları Demokratik Değerler Ölçeği”nin "eğitim hakkı", “özgürlük” ve "dayanışma” alt boyutlarında incelenmiştir.

Çalışmada kadın öğretmen adaylarının erkek öğretmen adaylarına oranla "özgürlük ve "dayanışma" alt boyutlarında daha fazla demokratik değerlere sahip olduğu gözlenmiştir. Kadın öğretmen adaylarının erkek öğretmen adaylarına oranla daha demokratik değerlere sahip olmalarının nedeninin kültürel kodlar olması muhtemel gözükmektedir. Kadın ve erkek cinslerinin yetiştirilme biçimlerinin önemli biçimde farklılaştığ 1 göz önünde 
bulundurulduğunda ortaya çıkan bu sonuç, erkeklerin kadınlara oranla daha otoriter olduğu yönündeki kültürel kodu da doğrular niteliktedir.

Diğer yandan sivil toplum kuruluşlarına üye olan öğretmen adaylarının bu tür örgütlere üye olmayan adaylara oranla daha fazla demokratik değerlere sahip oldukları saptanmıştır. Bu sonuç, sivil toplum kuruluşlarına üye olan bireylerin demokratik değerleri daha fazla benimsedikleri yönünde yorumlanabilir. Demokrasinin ve demokratik tutum ve değerlerin içselleştirilebilmesinin koşullarından biri de bireylerin örgütler aracılığg ile toplumsal istek ve beklentilerini ifade edebilmeleridir. Nitekim çağdaş toplumlarda her türlü siyasal katılım, siyasi partiler, sivil toplum kuruluşları, meslek örgütleri ve dernek gibi örgütler aracıllı̆ı ile gerçekleşebilmektedir. $\mathrm{Bu}$ ön kabuller 1şı̆̆ında, söz edilen bu tür örgütlere üye bireylerin neden daha demokratik tutumlar benimsedikleri anlaş1labilmektedir. $\mathrm{Bu}$ araştırmadan yola çıkılarak Ankara Üniversitesi Eğitim Bilimleri Fakültesi'nde okumakta olan erkek öğrencilere yönelik demokratik değer geliştirme eğitimleri düzenlenmesi önerilebilir.

Öğrencilerin öğretim elemanlarının demokratik tutumlarından olumlu yönde etkileneceği söylenebilir. Diğer bir deyişle, yalnızca özel olarak demokratik değer kazandırmaya yönelik dersler ya da kurslar değil, genel olarak öğretim elemanlarının diğer dersleri ve hatta öğrencilerce gözlenen ders dışı tutumları da genelde üniversite öğrencilerinin ve özelde öğretmen adaylarının demokratik değer kazanmalarında etkili olabilecektir.

$\mathrm{Bu}$ araştırmanın sınırlarını aşmamak kaydıyla, bireylere demokratik değer kazandırılmasının üniversiteye bırakılmadan daha alt öğretim düzeylerinden itibaren ele alınması gereken bir sorun olduğunu vurgulamakta yarar vardır. Bunun içinse öğrencilere örnek olacak “demokratik yurttaşlık modelleri”ne (bkz. Karaman-Kepenekçi, 2005) gereksinim vardır. Öğrenciler öğrenim yaşantılarının ilk yıllarından başlayarak karşılarında demokratik tutumlar sergileyen öğretmenler görmelidir.

$\mathrm{Bu}$ araştırmanın tüm eğitim fakültelerini kapsayacak şekilde genişletilerek tekrarlanması tüm öğretmen adayları hakkında bilgi sahibi olunması için önemlidir. Bu nedenle araştırmanın genişletilmiş bir örneklem üzerinde tekrarlanması önerilmektedir. 


\section{KAYNAKLAR}

Abay, A. R. (2004). Sivil Toplum ve Demokrasi Bağlamında Sivil Dayanışma ve Sivil Toplum Örgütleri. http://iibf.ogu.edu.tr/kongre/bildiriler/06.04.pdf adresinden 16.06.2008 tarihinde alınmıştır.

Aksoy, N. (2002). Sınıf İçi Kurallar. (Ed. Emin Karip). Sınıf Yönetimi. Ankara: Pegem A Yayıncilik.

Arslan, H. (2007). Sınıf Kuralları. (Eds. Mehmet Şişman ve Selahattin Turan). Sinıf Yönetimi. Ankara: Öğreti Yayınları.

Başar, H. (2006). Sinıf Yönetimi. Ankara: Anı Yayıncılık.

Başaran, İ. E. (2006). Türk Eğitim Sistemi ve Okul Yönetimi. Ankara: Ekinoks Yayınları.

Berends, M. (2006). Survey Methods in Educational Research. In J. L. Green, G. Camilli \& P. B. Elmore (Eds). Complementary Methods in Education Research. (pp. 623-640). USA: Lawrence Erlbaum Associates Publishers.

Büyüköztürk, Ş. (2005). Sosyal Bilimler İçin Veri Analizi El Kitabı. (Gözden Geçirilmiş 5. Bask1). Ankara: Pegem A Yayıncılık.

Chromy, J. (2006).Survey Sampling. In J. L. Green, G. Camilli \& P. B. Elmore (Eds). Complementary Methods in Education Research. (pp. 641-654). USA: Lawrence Erlbaum Associates Publishers.

Black, S. (2005). Listening to Students. American School Board Journal, November: $39-41$.

Demoulin, D.F. \& Kolstad, R. (2000). Assessing the gains of behavioral dynamics essential for success in democracy for teacher education students. College Student Journal. 34 (3), 417 - 422.

Dewey, J. (1965). Democracy and Education (Fifth edition). New York: The Macmillan Company.

Erdoğan, M. (1998). Liberal Toplum Liberal Siyaset. Ankara: Siyasal Kitapevi.

Fine, B. (1945). Democratic Education. New York: Thomas Y. Crowell Company.

Gömleksiz, M. N. ve Kan, A. Ü. (2008). Eğitim Fakültesi ve Tezsiz Yüksek Lisans Programlarına Kayıtlı Öğretmen Adaylarının Demokratik Tutumlarının Değerlendirilmesi. Milli Eğitim Dergisi, 178 (1), 44-64.

Karadağ, E., Baloğlu N., Yalçınkayalar, P. (2006). İlköğretim Okulu Yöneticilerinin Öğretmenler Tarafindan Algılanan Demokratik Tutumları ile Öğretmenlerin Demokratik Değerleri Üzerine İlişkisel Bir Araştırma. Değerler Ĕgitimi Dergisi, 4 (12), 65-82.

Karahan, T. F., Sardoğan, M. E., Özkamalı, E. ve Dicle, A. N. (2006). Öğretmen Adaylarında Demokratik Tutum, Nevrotik Eğilimler ve 
Kendini Gerçekleştirme. Hacettepe Üniversitesi Eğitim Fakültesi Dergisi, 30, 149-158.

Karakütük, K. (2001). Demokratik Laik Eğitim. Ankara: Anı Yayıncılık.

Karaman-Kepenekçi, Y. (2005). Okul Yönetiminde Demokrasi. Çankaya Ĕ̈itim. Ocak-Şubat-Mart, 14-15.

Karaman-Kepenekçi, Y. (2006). A Study of University Students' Attitudes toward Children's Rights in Turkey. The International Journal of Children's Rights. 14 (3), 307-319.

Middaugh, E. ve Perlstein, D. (2005). Thinking and Teaching in a Democratic Way: Hilda Taba and Ethos of Brown. Journal of Curriculum and Supervision, 20 (3), 234-256.

Moller, J. (2006). Democratic Schooling in Norway: Implications for Leadership in Practice. Leadership and Policy in Schools, 5 (1), 53-69.

Myers, J. P. (2008). Democratizing School Authority: Brazilian Teachers' Perceptions of the Election of Principals. Teaching and Teacher Education, 24, 952-966.

Okçabol, R. ve Gök, F. (1998). Öğretmen Profili Araştırması. Ankara: Eğitim-Sen Yayını.

Özden, Y. (2005). Ĕgitimde Yeni Değerler. Ankara: PegemA Yayıncılık.

Puolimatka, T. (1997). The Problem of Democratic Values Education. Journal of Philosophy of Education. 31 (3), 461-476.

Rowland, S. (2003). Teaching for Democracy in Higher Education. Teaching in Higher Education, 8 (1), 89-101.

Schweisfurth, M. (2002). Democracy and Teacher Education: negotiating practice in The Gambia. Comparative Education, 38 (3), 303-314.

Selvi, K. (2006). Developing a Teacher Trainees' Democratic Values Scale: Validity and Reliability Analyses. Social Behavior and Personality, 34 (9), 1171-1178.

Sharma, S. R. (2003). Encyclopedia of Value and Moral Education. New Delhi: Cosmo Publications.

Şaylan, G. (1998). Demokrasi ve Demokrasi Düşüncesinin Gelişmesi. Ankara: TODAİE Masaüstü Yayıncılık.

Tezcan, M. (1996). Eğitim Sosyolojisi. Ankara: Feryal Matbaas1.

Wragg, E. C. ve C. M. Wragg (1998). Classroom Management Research in the United Kingdom, Eric Document, 418971. 